\title{
Interaction of Titanium Dioxide with Formaldehyde in the Presence of Quartz Sand under Static and Dynamic Conditions
}

\author{
Anthi S. Stefanarou and Constantinos V. Chrysikopoulos * (D) \\ School of Environmental Engineering, Technical University of Crete, 73100 Chania, Greece; \\ anthi.stefanarou@gmail.com \\ * Correspondence: cvc@enveng.tuc.gr; Tel.: +30-6945373208
}

Citation: Stefanarou, A.S.

Chrysikopoulos, C.V. Interaction of Titanium Dioxide with Formaldehyde in the Presence of Quartz Sand under Static and Dynamic Conditions. Water 2021, 13, 1420. https://doi.org/ $10.3390 / w 13101420$

Academic Editor:

Chicgoua Noubactep

Received: 14 April 2021

Accepted: 18 May 2021

Published: 20 May 2021

Publisher's Note: MDPI stays neutral with regard to jurisdictional claims in published maps and institutional affiliations.

Copyright: (c) 2021 by the authors. Licensee MDPI, Basel, Switzerland This article is an open access article distributed under the terms and conditions of the Creative Commons Attribution (CC BY) license (https:// creativecommons.org/licenses/by/ $4.0 /)$.

\begin{abstract}
Formaldehyde (FA) is an extremely active compound that is widely used in numerous applications. Given that FA is a known carcinogen, it is essential to remove it from the environment. Titanium dioxide $\left(\mathrm{TiO}_{2}\right)$, due to its special physicochemical properties, is a promising adsorbent for the removal of specific organic compounds from aqueous solutions. In this study, the interaction of $\mathrm{TiO}_{2}$ with FA in the presence and absence of quartz sand, the most common mineral on the Earth's surface, was investigated under static and dynamic (batch) conditions, at $25^{\circ} \mathrm{C}$. The experimental data suggested that the sorption of $\mathrm{FA}$ onto $\mathrm{TiO}_{2}$ can be described adequately by a pseudo-second order kinetic model, indicating that the main sorption mechanism was chemisorption. It was observed that the combination of $\mathrm{TiO}_{2}$ and quartz sand could1 lead up to effective removal of FA from aqueous samples.
\end{abstract}

Keywords: titanium dioxide; formaldehyde; quartz sand; sorption

\section{Introduction}

Water supplies are increasingly polluted due to human activities, as the Earth's population grows [1]. Industrial, municipal and domestic waste is often discharged into water canals, rivers, streams and lakes [2]. This waste causes toxic chemical and bacterial contamination, which is responsible for several water-borne diseases. Among the most frequently occurring toxic organic substances in water is formaldehyde (FA), because of its extensive use in numerous applications by various industries including: textile, furniture, aquaculture, agriculture, tannery, petrochemical, and cosmetics [3-7].

FA can be formed from catalytic oxidation of methanol, water disinfection processes as a byproduct, or from combustion of natural organic materials [8-13]. The presence of FA in the water, may cause adverse effects to human health (cancer, cardiovascular disease, neurological disease, miscarriage etc.), the environment and the ecosystem. The recommended FA concentrations in drinking-water are less than $100 \mu \mathrm{g} / \mathrm{L}$ [14,15]. Typical FA concentrations in ozonated drinking-water are up to $30 \mu \mathrm{g} / \mathrm{L}[16,17]$. However, FA concentrations in surface waters have been reported in the range 1.2-9 $\mathrm{mg} / \mathrm{L}$ [18], and in industrial wastewaters in the range $0.2-10 \mathrm{~g} / \mathrm{L}$ [19-21]. Often, conventional water treatment methods are not sufficient to remove all types of pollutants, so the development of new advanced technologies for FA removal is a burning issue. Current methods for removing FA from water depend mainly on physical adsorption with a removal success rate of $60-65 \%$ [22] and chemical catalytic oxidation [23]. Many materials have been shown to be effective in adsorbing FA, such as activated carbon, clays and carbon nanotubes [24-27].

Nanotechnology research has increased in the recent years and many revolutionary developments have taken place in this field. Nanomaterials have been extensively studied due to their many applications in the fields of energy, electronics, biomedicine and environmental remediation [28-34]. Titanium dioxide $\left(\mathrm{TiO}_{2}\right)$ is a nanomaterial, which has been used extensively in various commercial applications and catalytic reactions due to its very good physical, optical, electrical, and stable structural properties $[35,36]$. It should 
be noted that $\mathrm{TiO}_{2}$ concentrations in effluents from urban wastewater treatment plants are in the range 10-100 mg/L [37]. $\mathrm{TiO}_{2}$ is the 4th most abundant metal in the world, and can be found in various minerals, mainly in rutile, brocite, and anatase, but also in the human body, ash and plants [38]. It should be noted that $\mathrm{TiO}_{2}$ is present in various widely used products, such as paints, paper, plastics, cosmetics, food and much more [39]. By $2025, \mathrm{TiO}_{2}$ production in the US alone is expected to increase to 52.5 million tons/year [40]. Additionally, the nanomaterial technology offers an economical and efficient alternative to water purification and disinfection. Adsorption processes have the advantage of effectively removing contaminants from the aqueous phase. $\mathrm{TiO}_{2}$ has been used as an adsorbent for the successful removal of organic compounds from water [41], as well as for the removal of $\mathrm{V}(\mathrm{V})$ and $\mathrm{Pb}(\mathrm{II})$ from aqueous solutions [42]. In addition, $\mathrm{TiO}_{2}$ nanocomposites are widely used as adsorbents to remove metal ions from industrial waste [43]. Therefore, the use of $\mathrm{TiO}_{2}$ nanoparticles as adsorbent could be a promising solution for environmental remediation [44].

There are only a few studies of FA adsorption onto $\mathrm{TiO}_{2}$ surfaces published in the literature. These studies concluded that FA binds weakly on the rutile $\mathrm{TiO}_{2}$ surface either in a monodentate configuration or in a bidentate fashion [45-47], and on the anatase $\mathrm{TiO}_{2}$ surface in a monodentate configuration, with a small repulsive interaction, where co-adsorbed FA molecules can aggregate due to weak attractions [48].

Given that both $\mathrm{FA}$ and $\mathrm{TiO}_{2}$ are frequently released into the environment, they can easily infiltrate subsurface formations. It should be noted that the adsorption of FA onto quartz sand was reported to be weak [27]. Consequently, it is worthwhile to study the interaction between $\mathrm{FA}$ and $\mathrm{TiO}_{2}$ in the presence of a common rock-forming mineral such as quartz sand. Although the sorption of FA on single crystal rutile, as well as anatase $\mathrm{TiO}_{2}$ surfaces, has been studied from a physical chemistry view point [45-48], the kinetics of FA sorption onto a mixture of rutile and anatase $\mathrm{TiO}_{2}$ nanoparticles in the presence of quartz sand from an environmental engineering view point, to our knowledge, has not been reported before in the literature. In the present study, kinetic batch experiments were conducted under both static and dynamic conditions in order to investigate the interaction of FA with $\mathrm{TiO}_{2}$ in the presence of quartz sand. The results of this study could lead to the development of a new FA remediation technique based on $\mathrm{TiO}_{2}$ nanoparticles and quartz sand.

\section{Materials and Methods}

The initial FA stock solution (1000 mg/L) was prepared by placing $124 \mu \mathrm{L}$ of $37 \mathrm{wt} \%$ FA solution (Sigma-Aldrich $\geq 99 \%$ ) with a plunger pipette, into a $50 \mathrm{~mL}$ volumetric flask, and adding distilled deionized water $\left(\mathrm{ddH}_{2} \mathrm{O}\right)$ to the volumetric mark. From this concentrated stock solution numerous diluted solutions were made by adding $\mathrm{dd}_{2} \mathrm{O}$, in order to obtain the desired FA solution concentration for each individual experiment conducted in this study. Due to the fact that FA reacts with light, all FA solutions were covered with foil and stored in a darkroom at $4{ }^{\circ} \mathrm{C}$ [49].

For the detection of FA, the Nash method [50] was used, as outlined by Fountouli et al. [27]. For the preparation of $100 \mathrm{~mL}$ of Nash reagent solution, $0.2 \mathrm{~mL}$ of acetyl acetone, $0.3 \mathrm{~mL}$ of acetic acid, and $15 \mathrm{~g}$ of ammonium acetate were dissolved in $\mathrm{ddH}_{2} \mathrm{O}$. Equal volumes of Nash reagent and FA solution were mixed in order to form a yellowish product, diacetyl dihydrolutidine (DDL), which was determined spectrophotometrically at $625 \mathrm{~nm}$ with a UV-Vis spectrophotometer (UV-1900 Shimadzu, Japan). The necessary calibration curve of the FA peak area versus FA concentration was constructed by linear regression of the experimental data obtained using FA sample solutions $(5 \mathrm{~mL}$ of Nash reagent with $5 \mathrm{~mL}$ of FA), where 1, 2, 4, 6 and $8 \mathrm{mg} / \mathrm{L} \mathrm{FA}$ solutions were prepared by diluting the concentrated FA stock solution. 
To lower the $\mathrm{pH}$ of solutions, a $0.1 \mathrm{M}$ solution of hydrogen chloride $(\mathrm{HCl})$ was prepared by diluting with $\mathrm{ddH}_{2} \mathrm{O}, 3.04 \mathrm{~mL}$ of a concentrated $\mathrm{HCl}$ solution $(1.2 \mathrm{~g} / \mathrm{mL})$ to a final volume of $1000 \mathrm{~mL}$. To alkalize solutions, a $0.6 \mathrm{M}$ sodium hydroxide $(\mathrm{NaOH})$ solution was prepared by adding $2.4 \mathrm{~g} \mathrm{NaOH}$ to $100 \mathrm{~mL}$ of $\mathrm{ddH}_{2} \mathrm{O}$.

The $\mathrm{TiO}_{2}$ nanoparticles used in this study were a mixture of rutile and anatase $(99.5 \%$, molecular weight: 79.87, Sigma-Aldrich, St. Louis, MO, USA). Based on the BET laboratory analysis reported by the manufacturer, the size of the $\mathrm{TiO}_{2}$ nanoparticles was less than $25 \mathrm{~nm}$. The initial $\mathrm{TiO}_{2}$ stock solution $(100 \mathrm{mg} / \mathrm{L})$ was prepared by placing $100 \mathrm{mg}$ of $\mathrm{TiO}_{2}$ (mixture of rutile and anatase), into a $1000 \mathrm{~mL}$ volumetric flask, and adding $\mathrm{ddH}_{2} \mathrm{O}$ to the volumetric mark.

In this study, quartz sand was used as a sorbent, because it is the most common mineral on the surface of the Earth. The quartz sand (Filcom, Sibelco Co, Wessem, Netherlands) had size range 400 to $800 \mu \mathrm{m}$, specific density $2.6 \mathrm{gr} / \mathrm{cm}^{3}$, hardness $7 \mathrm{Mohs}$, and mass density $=1.6 \mathrm{t} / \mathrm{m}^{3}$. The chemical analysis of quartz sand is: $96.2 \% \mathrm{SiO}_{2}, 0.15 \% \mathrm{Na}_{2} \mathrm{O}, 0.02 \% \mathrm{MgO}$, $1.75 \% \mathrm{Al}_{2} \mathrm{O}_{3}, 0.03 \% \mathrm{P}_{2} \mathrm{O}_{5}, 0.06 \% \mathrm{SO}_{3}, 0.78 \% \mathrm{~K}_{2} \mathrm{O}, 0.11 \% \mathrm{CaO}, 0.46 \% \mathrm{Fe}_{2} \mathrm{O}_{3}, 0.02 \% \mathrm{BaO}$, $0.01 \% \mathrm{Mn} 3 \mathrm{O} 4$, and $0.41 \%$ loss on ignition. The quartz sand was cleaned with a frequently employed procedure [51-53]. Note that the number of attachment sites per unit volume of the quartz sand is increasing with decreasing quartz sand size [54].

Two different series of batch experiments (with and without quartz sand) were performed at $25{ }^{\circ} \mathrm{C}$. Each series incorporated both static and dynamic experiments. All batch experiments were performed in $20 \mathrm{~mL}$ Pyrex glass screw cap tubes (Fisher Scientific), which were thoroughly washed with detergent, and oven dried overnight. For each series of experiments, 20 glass tubes were employed, 10 for the dynamic experiments and 10 for the static experiments. The static experiments were performed with the tubes placed on a simple tube holder, whereas the dynamic experiments were performed with the tubes placed on a tube rotator, operated at $12 \mathrm{rpm}$ for complete mixing of the liquid solution. One glass tube from each group (static and dynamic) was selected at random at a preselected time periods $(5,15,30,45,60,90,120,150,180,240 \mathrm{~min})$. The liquid samples collected from each glass tube were centrifuged at 30,000 rpm for $10 \mathrm{~min}$ to precipitate the suspended $\mathrm{TiO}_{2}$ nanoparticles and leave only FA in the supernatant. Exactly $5 \mathrm{~mL}$ of the supernatant were added to $5 \mathrm{~mL}$ of Nash reagent, and the resulting mixture was analyzed by UV-visible spectroscopy. The following parameters were examined in both series of experiments (with and without quartz sand): $\mathrm{pH} 4,7.5$ and 10 , ionic strength (Is) 1, 50, and $100 \mathrm{mM}$, and FA concentration of 3,5 , and $8 \mathrm{mg} / \mathrm{L}$. The $\mathrm{TiO}_{2}$ concentration in all experiments was equal to $100 \mathrm{mg} / \mathrm{L}$. Additionally, $14 \mathrm{~g}$ for quartz sand were added to each of the 20 glass tubes of the second series of batch experiments. A schematic illustration of the experimental procedures is presented in Figure 1. 


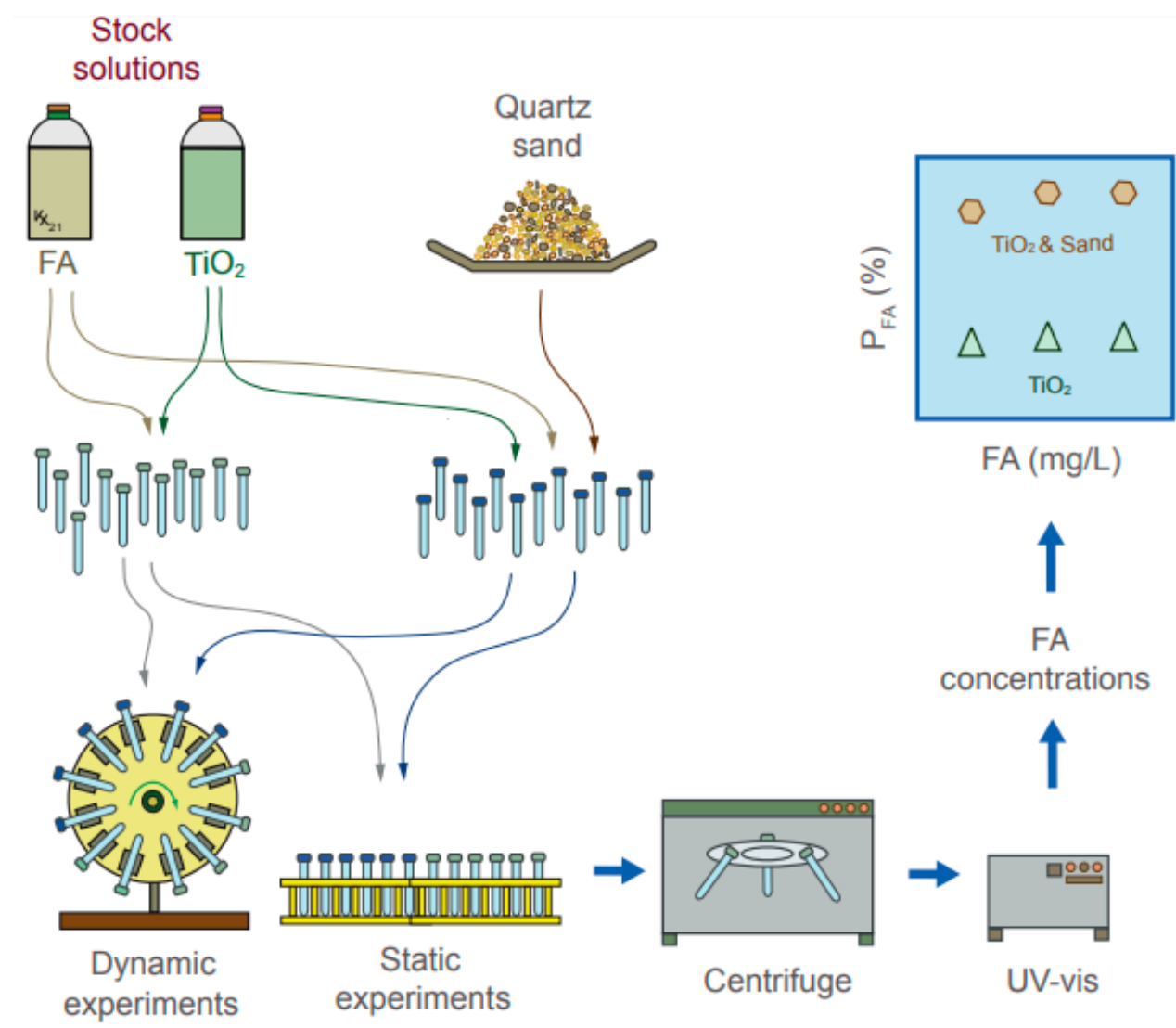

Figure 1. Experimental setup, showing how the glass screw cap tubes were filled for the dynamic and static experiments and the subsequent FA detection analysis.

\section{Theoretical Considerations}

The FA concentrations sorbed onto either $\mathrm{TiO}_{2}$ or quartz sand at time $\mathrm{t}, \mathrm{C}_{\mathrm{t}}^{*}$ (mg FA/g solids), were determined by the following equation [26]:

$$
\mathrm{C}_{\mathrm{t}}^{*}=\frac{\left(\mathrm{C}_{0}-\mathrm{C}_{\mathrm{t}}\right) \mathrm{V}}{\mathrm{W}}
$$

where $\mathrm{C}_{0}$ (mg FA/L solution) is the initial liquid phase FA concentration, $\mathrm{C}_{\mathrm{t}}(\mathrm{mg}$ FA/L solution) is the liquid phase FA concentration at time $\mathrm{t}, \mathrm{V}$ (L solution) is the volume of the solution, and $\mathrm{W}$ (g sorbent) is the dry mass of the sorbent.

If more than one sorbent is used at the same time, the following expression provides the total mass removed from solution by all sorbents used, as opposed to the mass sorbed to each sorbent separately. In order to evaluate the efficiency of the sorption process, to each sorbent individually or combined, the percentage of FA removal, $\mathrm{P}_{\mathrm{FA}}(\%)$, at a given time was determined by [26]:

$$
\mathrm{P}_{\mathrm{FA}}=\frac{\left(\mathrm{C}_{0}-\mathrm{C}_{\mathrm{t}}\right)}{\mathrm{C}_{0}} \times 100
$$

Preliminary analysis of the experimental data collected in this study showed that the sorption process is best described by a pseudo-second order model expressed by the following differential relation [55]:

$$
\frac{\mathrm{dC}_{\mathrm{t}}^{*}}{\mathrm{dt}}=\mathrm{k}_{\mathrm{p} 2}\left(\mathrm{C}_{\mathrm{eq}}^{*}-\mathrm{C}_{\mathrm{t}}^{*}\right)^{2}
$$


where $t(d)$ is time, $k_{p 2}$ (g sorbent/(mg FA) $d$ ) is the rate constant of the pseudo-secondorder sorption model, and $\mathrm{C}_{\mathrm{eq}}^{*}(\mathrm{mg} \mathrm{FA} / \mathrm{g}$ sorbent) is the FA concentration sorbed onto the solids at equilibrium. The above equation can be solved by separation of variables followed by integration over time from 0 to $t$ to yield:

$$
\mathrm{C}_{\mathrm{t}}^{*}=\frac{\left(\mathrm{C}_{\mathrm{eq}}^{*}\right)^{2} \mathrm{k}_{\mathrm{p} 2 \mathrm{t}}}{1+\mathrm{C}_{\mathrm{eq}}^{*} \mathrm{k}_{\mathrm{p} 2 \mathrm{t}}}
$$

In addition, the above equation can be rearranged in the following linear form:

$$
\frac{\mathrm{t}}{\mathrm{C}_{\mathrm{t}}^{*}}=\frac{1}{\mathrm{k}_{\mathrm{p} 2}\left(\mathrm{C}_{\mathrm{eq}}^{*}\right)^{2}}+\frac{\mathrm{t}}{\mathrm{C}_{\mathrm{eq}}^{*}}
$$

The pseudo-second-order model suggests that the sorption mechanism is governed by chemical sorption (chemosorption), where electron exchange takes place between the sorbed chemical and the sorbent [56]. Certainly, the pseudo-second-order kinetic sorption model has been employed successfully in several sorption studies of environmental interest $[27,57,58]$. In this study, the pseudo-second order kinetics model was fitted to the experimental data with the public domain nonlinear least squares regression software ColloidFit [59].

\section{Results and Discussion}

The experimental data collected from each FA sorption experiment conducted in this study, at various conditions, were used to evaluate the corresponding percentage of FA removal, $\mathrm{P}_{\mathrm{FA}}(\%)$, at equilibrium. The results are presented graphically in Figure 2. Clearly, the $\mathrm{P}_{\mathrm{FA}}$ values were higher in the presence of both $\mathrm{TiO}_{2}$ nanoparticles and quartz sand $\left(\mathrm{P}_{\mathrm{FA}}>80 \%\right)$, than only $\mathrm{TiO}_{2}$ nanoparticles $\left(\mathrm{P}_{\mathrm{FA}} \sim 40 \%\right)$, for both static and dynamic conditions. This is an anticipated result, because generally FA is poorly sorbed onto $\mathrm{TiO}_{2}$ nanoparticles [60] and very weakly onto quartz sand [27], but in the presence of both $\mathrm{TiO}_{2}$ nanoparticles and quartz sand, FA can access more sorption sites on the two different sorbents. No clear effect of FA concentration, $\mathrm{pH}$, and Is on the percentage of FA removal could be detected from these results. Certainly, the experimental data presented in Figure 2 shown that the combined use of sorbents $\left(\mathrm{TiO}_{2}\right.$ nanoparticles and quartz sand) resulted in higher FA removal than the cases where only $\mathrm{TiO}_{2}$ nanoparticles were used. Certainly, the interactions between $\mathrm{TiO}_{2}$ nanoparticles and quartz sand enhanced FA removal from the liquid phase. Therefore, the presence of quartz sand is expected to be helpful in FA removal from aqueous solutions.

The kinetic experiments of FA sorption onto $\mathrm{TiO}_{2}$ nanoparticles, with FA initial concentrations of 3,5 and $8 \mathrm{mg} / \mathrm{L}$ and $\mathrm{TiO}_{2}$ concentration of $100 \mathrm{mg} / \mathrm{L}$, under dynamic and static conditions are presented in Figure 3. It is evident from the experimental data that equilibrium occurred within the first $15 \mathrm{~min}$ of the experimental duration. As expected, the amount of FA sorbed onto $\mathrm{TiO}_{2}$ nanoparticles is higher for the dynamic than static conditions due to agitation. Initially, $\mathrm{FA}$ was sorbed quickly onto $\mathrm{TiO}_{2}$ nanoparticles due to the large number of adsorption sites available. As the sorption process continued, the sorption rate decreased due to the reduction of available sorption sites [61]. Fast FA sorption has also been observed in other similar studies [27,62]. In addition, note that FA sorption onto $\mathrm{TiO}_{2}$ nanoparticles was directly proportional to the $\mathrm{FA}$ initial concentration. This is an anticipated result, which has also been observed in other similar sorption studies [27]. 


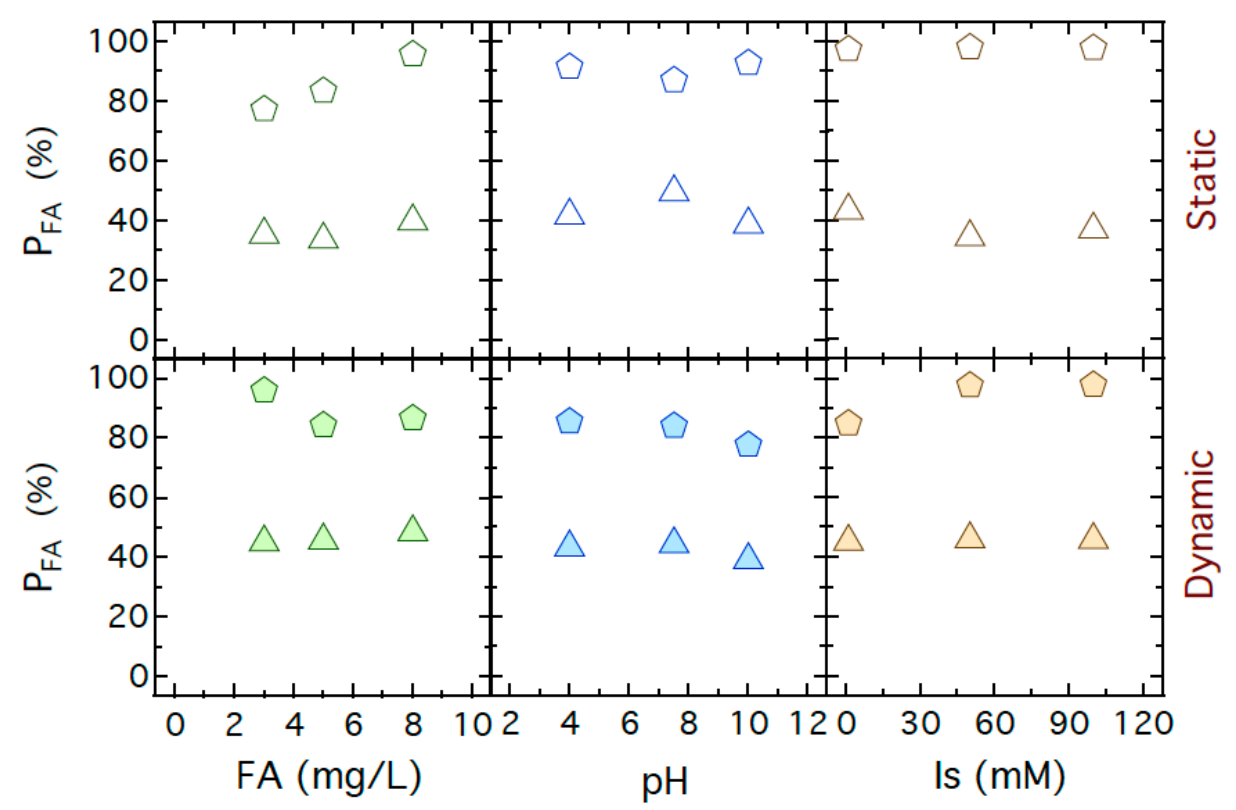

Figure 2. Percentage of FA removal, $\mathrm{P}_{\mathrm{FA}}(\%)$, at equilibrium onto $\mathrm{TiO}_{2}$ (triangles) and both $\mathrm{TiO}_{2}$ and quartz sand (pentagons), under static (open symbols) and dynamic (filled symbols) conditions, for three different values of initial FA concentration $(3,5,8 \mathrm{mg} / \mathrm{L}), \mathrm{pH}(4,7.5,10)$, and Is $(1,50,100 \mathrm{mM})$.

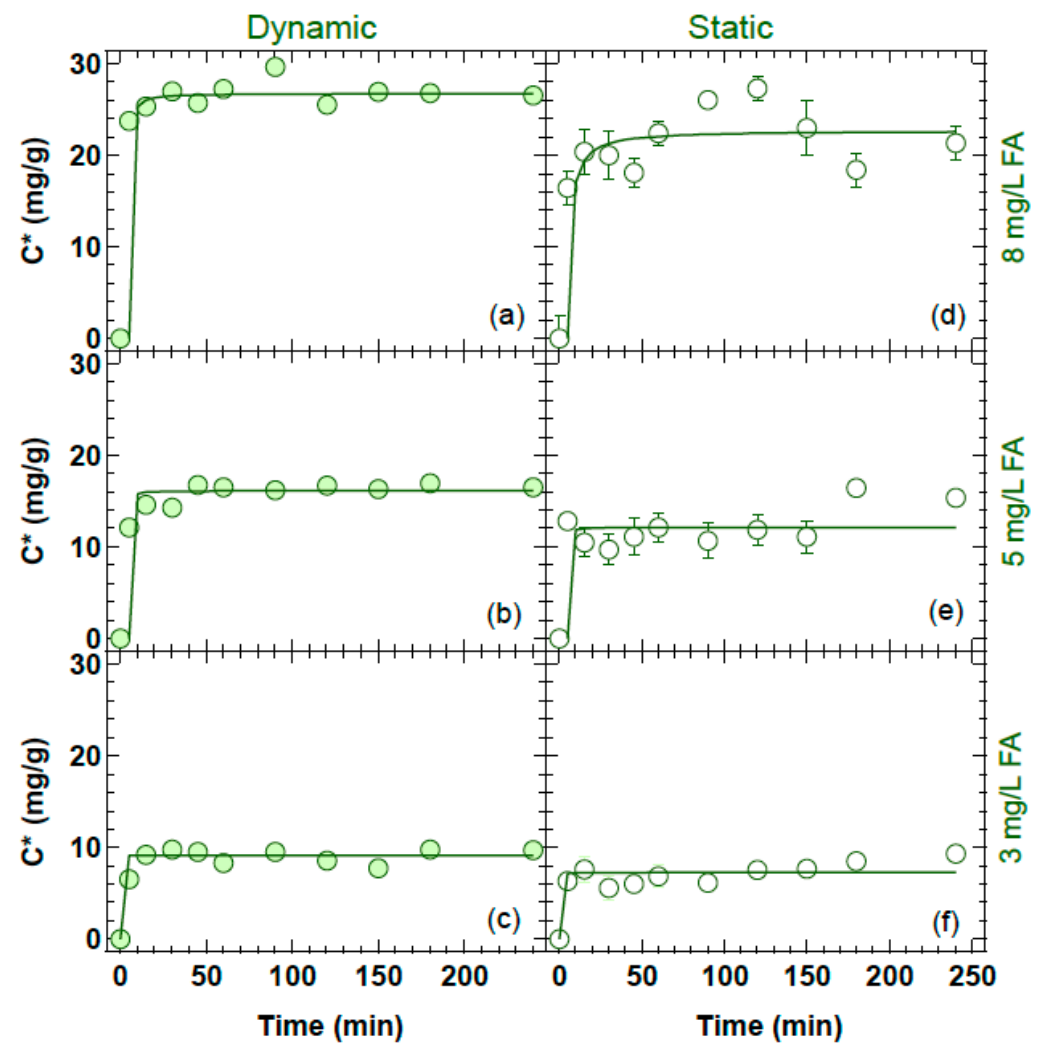

Figure 3. FA sorbed concentrations onto $\mathrm{TiO}_{2}$ nanoparticles as a function of time, under dynamic (a-c: filled circles) and static (d-f: open circles) conditions, for three different initial FA concentrations. The $\mathrm{TiO}_{2}$ concentration was $100 \mathrm{mg} / \mathrm{L}$ and the temperature $25^{\circ} \mathrm{C}$. The curves represent the fitted pseudo-second order model. Error bars not shown are smaller than the size of the symbol.

The kinetic experiments of FA sorption onto $\mathrm{TiO}_{2}$ nanoparticles at $\mathrm{pH}$ values of 4, 7.5, and 10 , with FA initial concentration of $5 \mathrm{mg} / \mathrm{L}$ and $\mathrm{TiO}_{2}$ concentration of $100 \mathrm{mg} / \mathrm{L}$, under dynamic and static conditions are shown in Figure 4. The experimental data suggested 
that FA sorption onto $\mathrm{TiO}_{2}$ nanoparticles was affected weakly by $\mathrm{pH}$. The highest FA sorption was observed at $\mathrm{pH} 7.5$ and the lowest at $\mathrm{pH} 10$. This is consistent with previous studies where at $\mathrm{pH}<7$, FA removal was reported to increase due to the positively charged hydrogen ion accumulation around the adsorbent surface [63-65].

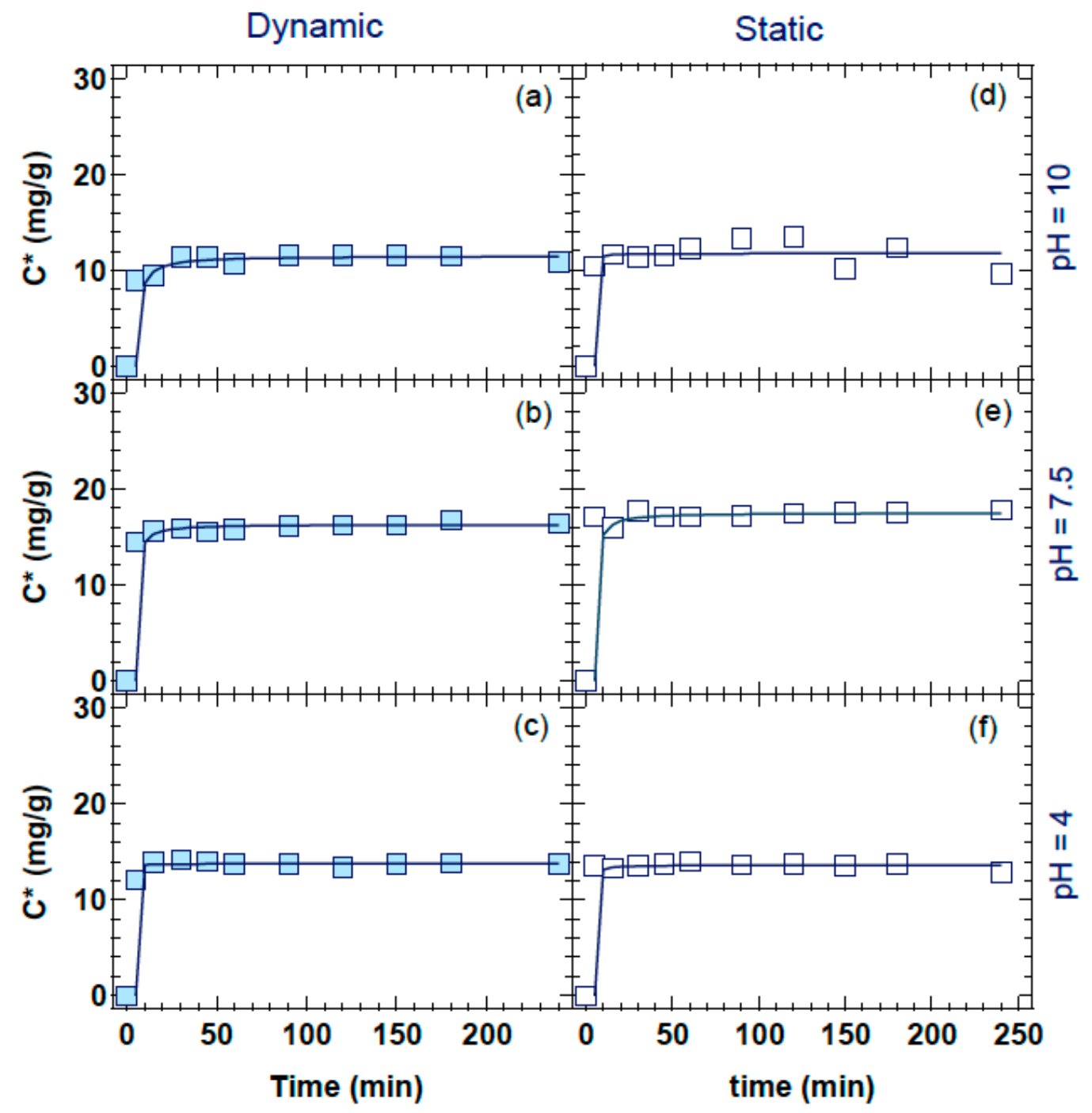

Figure 4. FA sorbed concentrations onto $\mathrm{TiO}_{2}$ nanoparticles as a function of time, under dynamic (a-c: filled squares) and static (d-f: open squares) conditions, for three different $\mathrm{pH}$ values. The initial FA concentration was $5 \mathrm{mg} / \mathrm{L}, \mathrm{TiO}_{2}$ concentration $100 \mathrm{mg} / \mathrm{L}$ and the temperature $25^{\circ} \mathrm{C}$. The curves represent the fitted pseudo-second order model.

The kinetic experiments of FA sorption onto $\mathrm{TiO}_{2}$ nanoparticles at solution ionic strengths (Is) of 1, 50, and $100 \mathrm{mM}$, with FA initial concentration of $5 \mathrm{mg} / \mathrm{L}$ and $\mathrm{TiO}_{2}$ concentration of $100 \mathrm{mg} / \mathrm{L}$, under dynamic and static conditions are shown in Figure 5 . The experimental data suggested that FA sorption onto $\mathrm{TiO}_{2}$ nanoparticles is practically unaffected by the imposed Is changes under dynamic conditions, whereas a slight FA sorption decrease was observed at the higher Is values (compare Figure 5d,e). This is in agreement with an earlier study reported in the literature where Is variations did not yield significant changes in the FA sorption process [27]. 


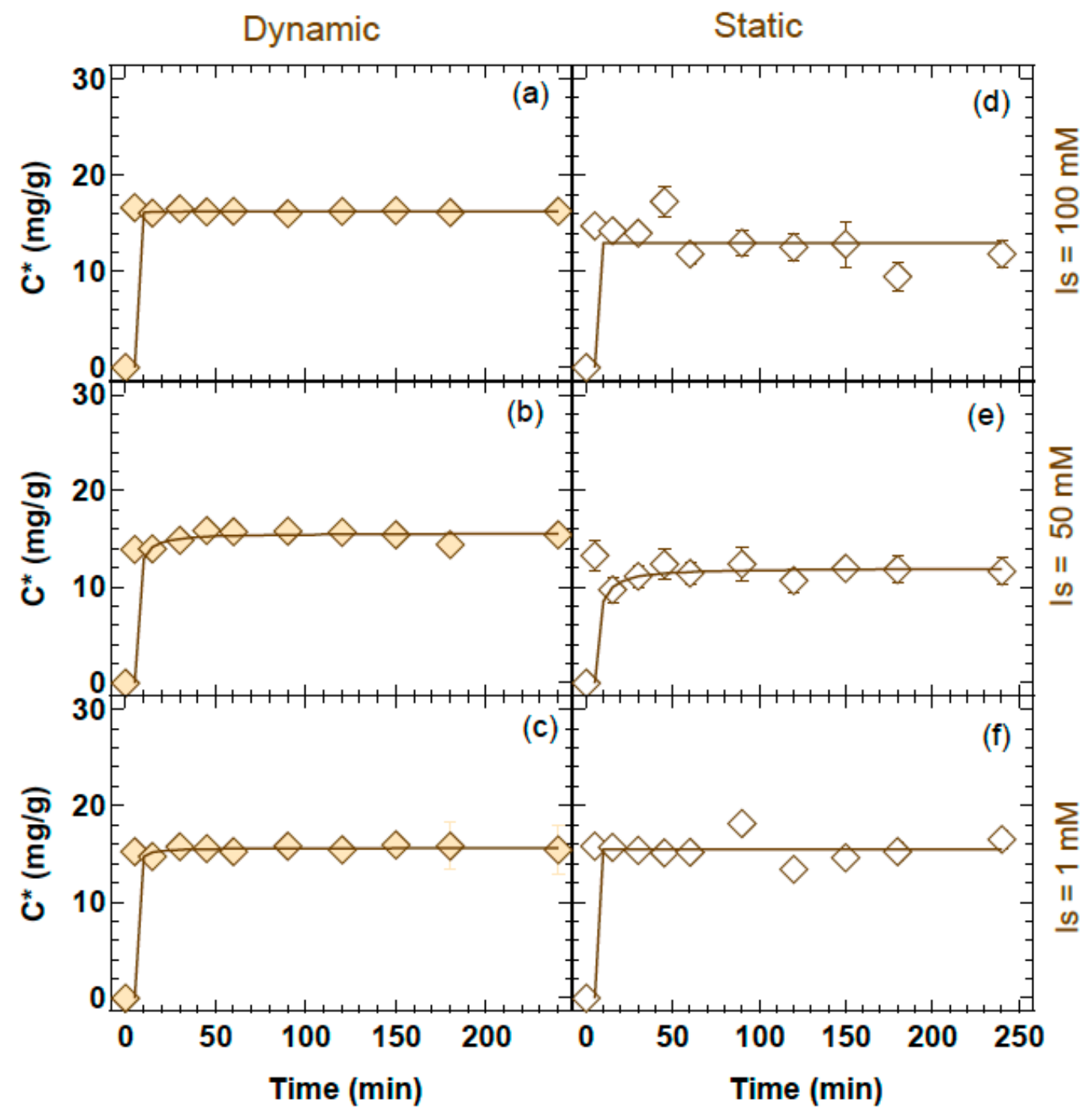

Figure 5. FA sorbed concentrations onto $\mathrm{TiO}_{2}$ nanoparticles as a function of time, under dynamic (a-c: filled diamonds) and static (d-f: open diamonds) conditions, for three different ionic strength (Is) values. The initial FA concentration was $5 \mathrm{mg} / \mathrm{L}, \mathrm{TiO}_{2}$ concentration $100 \mathrm{mg} / \mathrm{L}$ and the temperature $25{ }^{\circ} \mathrm{C}$. The curves represent the fitted pseudo-second order model. Error bars not shown are smaller than the size of the symbol.

The kinetic experiments of FA sorption onto $\mathrm{TiO}_{2}$ nanoparticles in the presence of $14 \mathrm{~g}$ quartz sand, with FA initial concentrations of 3,5 and $8 \mathrm{mg} / \mathrm{L}$ and $\mathrm{TiO}_{2}$ concentration of $100 \mathrm{mg} / \mathrm{L}$, under dynamic and static conditions are shown in Figure 6. The experimental results indicated that equilibrium was achieved faster (within the first $5 \mathrm{~min}$ ) in the presence of quartz sand compared to the case where the quartz sand was absent. This was attributed to the additional sorption sites on the quartz sand. It is worth noting that the mass of $\mathrm{TiO}_{2}$ nanoparticles $(100 \mathrm{mg})$ used in these experiments was significantly smaller compared to the added mass of quartz sand (14 g). Clearly, the sorption process depended strongly on the concentration of FA, as well as the concentration of the available sorbents. In general, the extent of solute sorption increased with increasing sorbent concentration. Note that by increasing the sorbent concentration led to an augmented number of available sorption sites. However, the total amount of solute sorbed per unit weight of sorbent may decrease after increasing the sorbent concentration due to interference caused by the interaction of the active sites of the sorbent [66-68]. In this study, instead of increasing the $\mathrm{TiO}_{2}$ concentration, another sorbent (quartz sand) was added in each Pyrex glass screw cap tube, which did not yield any interference but, as expected, increased the sorption sites. 
The observed FA sorption increase when the both sorbents $\left(\mathrm{TiO}_{2}\right.$ nanoparticles and quartz sand) were used simultaneously was similar to the FA sorption increase, reported in the literature, when clay particles and quartz sand were used together as sorbents [69].

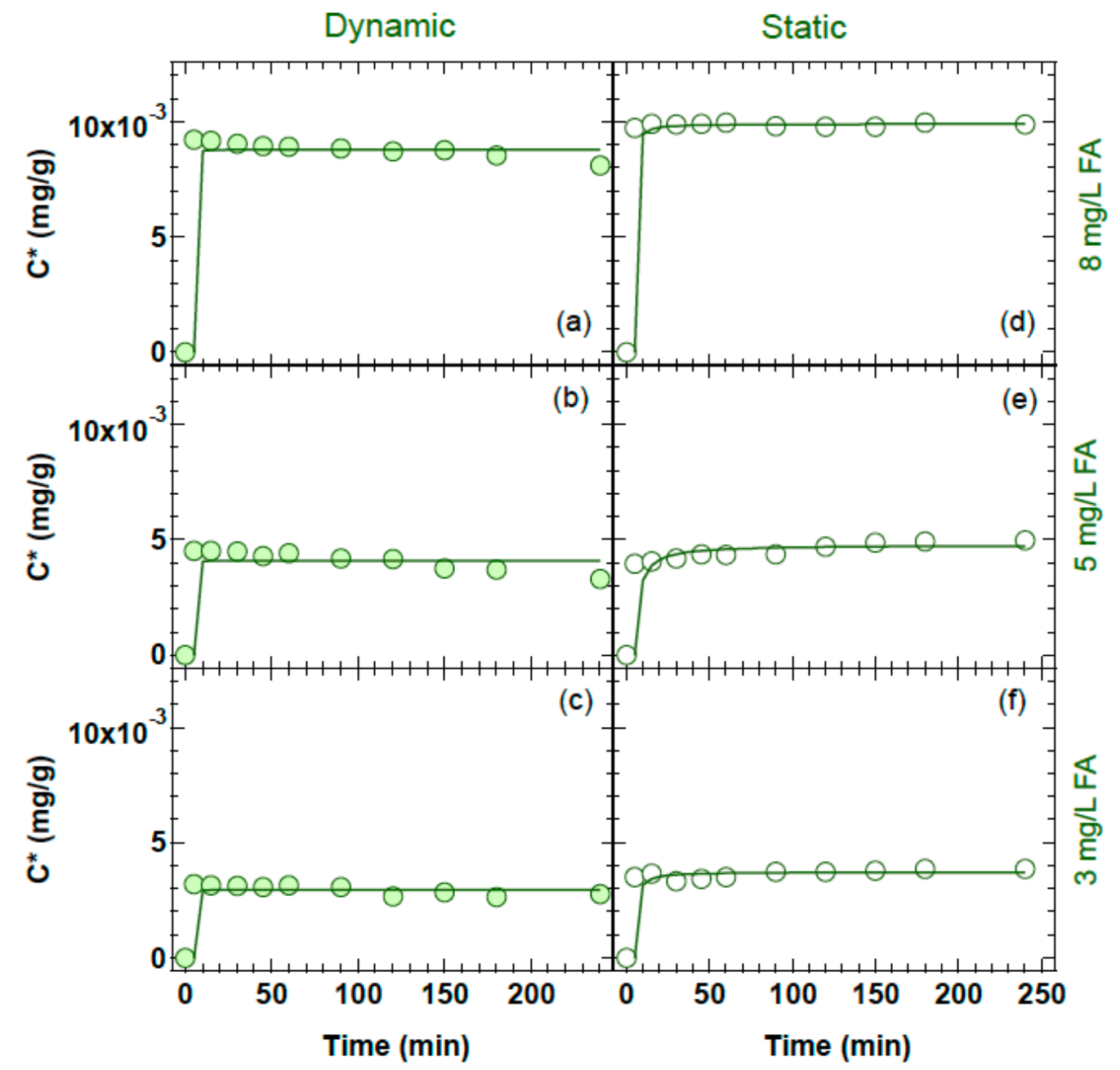

Figure 6. FA sorbed concentrations onto $\mathrm{TiO}_{2}$ nanoparticles and quartz sand as a function of time, under dynamic (a-c: filled circles) and static (d-f: open circles) conditions, for three different initial FA concentrations. The $\mathrm{TiO}_{2}$ concentration was $100 \mathrm{mg} / \mathrm{L}$, the mass of quartz sand added in each Pyrex glass screw cap tube was $14 \mathrm{~g}$, and the temperature $25^{\circ} \mathrm{C}$. The curves represent the fitted pseudo-second order model.

The kinetic experiments of $\mathrm{FA}$ sorption onto $\mathrm{TiO}_{2}$ nanoparticles in the presence of $14 \mathrm{~g}$ quartz sand at $\mathrm{pH}$ values of $4,7.5$, and 10 , with $\mathrm{FA}$ initial concentration of $5 \mathrm{mg} / \mathrm{L}$ and $\mathrm{TiO}_{2}$ concentration of $100 \mathrm{mg} / \mathrm{L}$, under dynamic and static conditions are shown in Figure 7. The experimental data clearly shown that changes in solution $\mathrm{pH}$ did not affect the FA sorption process. Clearly, that the sorbed FA concentration was very similar in all three $\mathrm{pH}$ cases $(4,7.5$ and 10) considered in this study. A possible explanation for this is that all the $\mathrm{pH}$ values used in this study were higher than the isoelectric point $\mathrm{pH}_{\mathrm{IEP}}=3.5$ for the mixture of rutile and anatase [31], which is close to other values reported in the literature [70]. Note that $\mathrm{pH}$ IEP values for $\mathrm{TiO}_{2}$ nanoparticles may vary significantly depending on the manufacturer [71]. Given that the electrophoretic mobility of the rutile and anatase mixture did not alter direction over the range of the $\mathrm{pH}$ values used in this study, the nature of the repulsive forces between the $\mathrm{TiO}_{2}$ nanoparticles remained unchanged. 


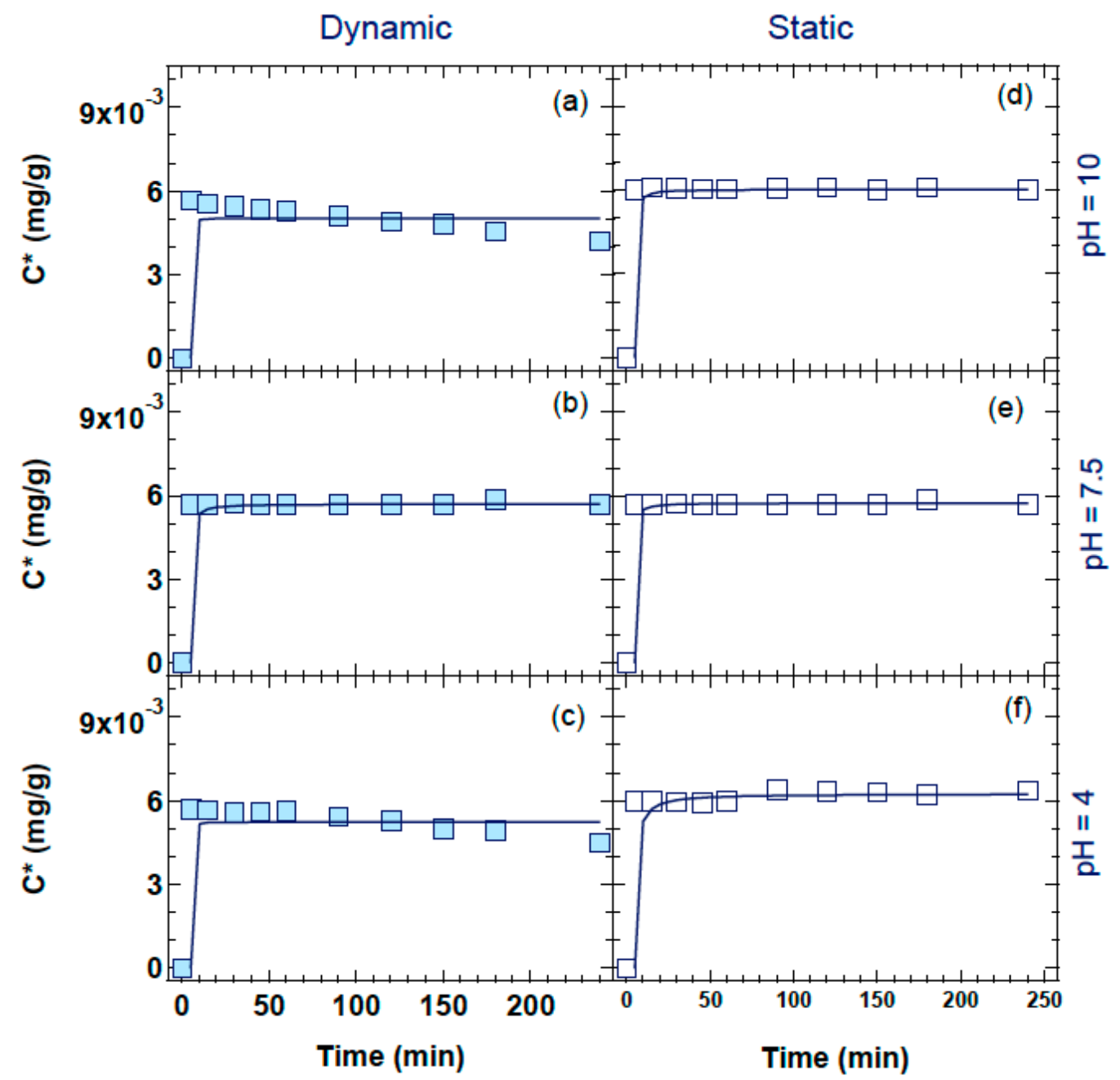

Figure 7. FA sorbed concentrations onto $\mathrm{TiO}_{2}$ nanoparticles and quartz sand as a function of time, under dynamic (a-c: filled squares) and static (d-f: open squares) conditions, for three different $\mathrm{pH}$ values. The initial FA concentration was $5 \mathrm{mg} / \mathrm{L}, \mathrm{TiO}_{2}$ concentration $100 \mathrm{mg} / \mathrm{L}$, the mass of quartz sand added in each Pyrex glass screw cap tube was $14 \mathrm{~g}$, and the temperature $25^{\circ} \mathrm{C}$. The curves represent the fitted pseudo-second order model.

The kinetic experiments of FA sorption onto $\mathrm{TiO}_{2}$ nanoparticles in the presence of $14 \mathrm{~g}$ quartz sand at solution ionic strengths (Is) of 1, 50, and $100 \mathrm{mM}$, with FA initial concentration of $5 \mathrm{mg} / \mathrm{L}$ and $\mathrm{TiO}_{2}$ concentration of $100 \mathrm{mg} / \mathrm{L}$, under dynamic and static conditions are shown in Figure 8. The experimental data shown that changes in the solution ionic strength did not affect significantly FA sorption. Only in the experiment for Is $=100 \mathrm{mM}$, the amount of FA sorbed onto $\mathrm{TiO}_{2}$ nanoparticles and quartz sand decreased slightly with increasing ionic strength. This was most likely due to the increased competition between positively charged FA species and cationic electrolytes for active sorption sites. This observation was consistent with other studies of organic compound uptake by soils [72]. Also, at higher Is values the aggregation of $\mathrm{TiO}_{2}$ nanoparticles was enhanced [73], which in turn led to a reduction of available sites for FA sorption.

The data collected from the dynamic experiments in the presence of quartz sand revealed that after the sorbed FA concentration reached a maximum value, in several cases, there was a small gradual decrease in $C^{*}$ (see Figures 6-8). This reduction was attributed to desorption caused by agitation due to the rotation of the Pyrex glass screw cap tubes, or to possible $\mathrm{TiO}_{2}$ nanoparticle interactions with the quartz sand. It should be noted that $\mathrm{TiO}_{2}$ nanoparticles can also attach onto the quartz sand [33]. 


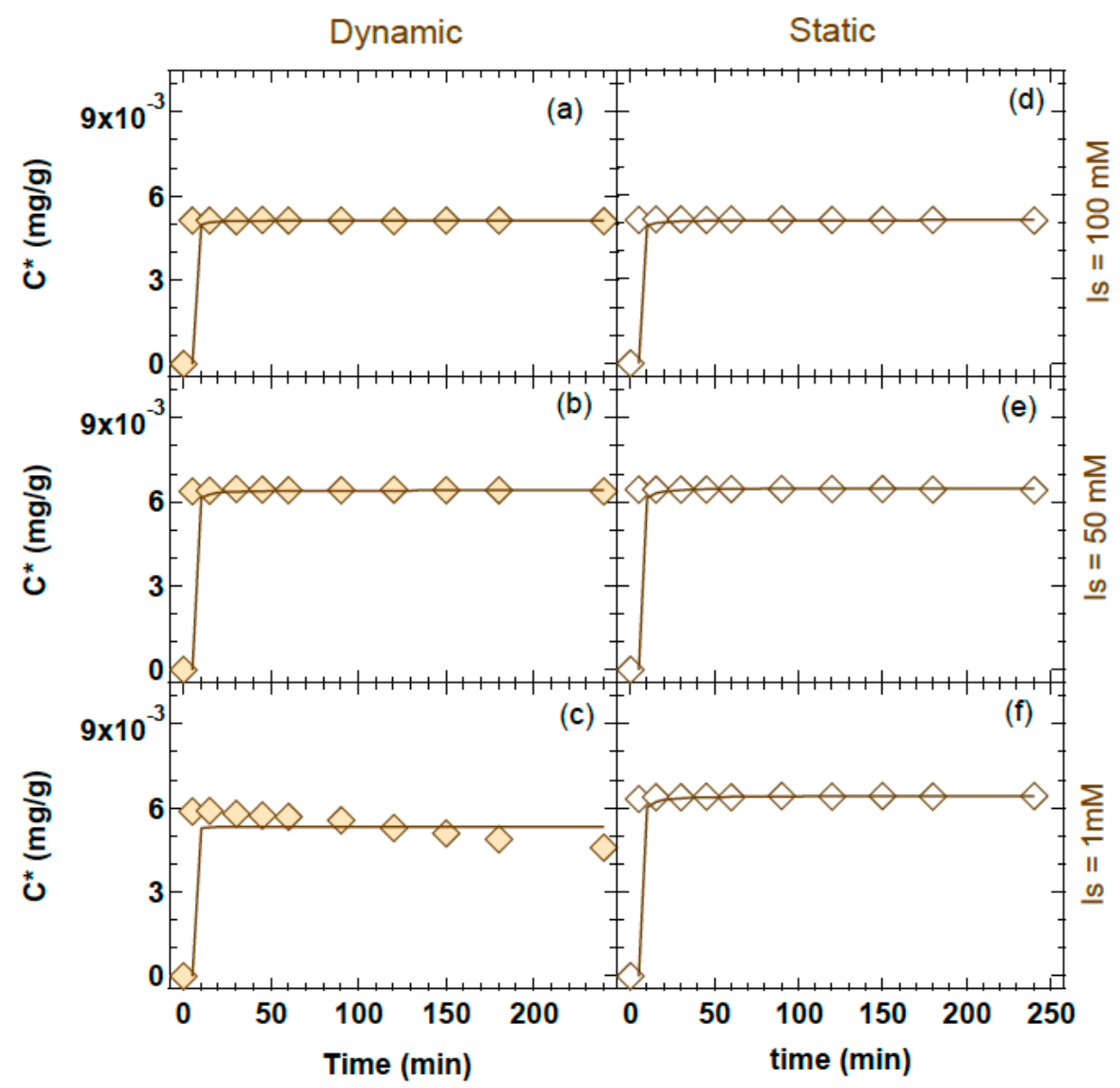

Figure 8. FA sorbed concentrations onto $\mathrm{TiO}_{2}$ nanoparticles and quartz sand as a function of time, under dynamic (a-c: filled diamonds) and static (d-f: open diamonds) conditions, for three different ionic strength (Is) values. The initial FA concentration was $5 \mathrm{mg} / \mathrm{L}, \mathrm{TiO}_{2}$ concentration $100 \mathrm{mg} / \mathrm{L}$, the mass of quartz sand added in Pyrex glass screw cap tube was $14 \mathrm{~g}$, and the temperature $25^{\circ} \mathrm{C}$. The curves represent the fitted pseudo-second order model.

The data collected from each experiment were very well fitted with the pseudo-second order model (see Figures 3-8), suggesting that chemical sorption (chemisorption) was involved in the process [56]. The corresponding fitted values of the reaction rate constant of the pseudo-second order model $\left(\mathrm{kp}_{2}\right)$ and the FA concentration sorbed onto the solids at equilibrium $\left(\mathrm{C}_{\mathrm{eq}}^{*}\right)$ are listed in Table 1. Clearly, the fitted $\mathrm{kp}_{2}$ values for the experiments conducted in the presence of quartz sand were much higher than those in the absence of quartz sand. Additionally, $\mathrm{kp}_{2}$ values were consistently higher under dynamic than static conditions due to agitation. In general, FA sorption was faster in the presence, compared to the absence, of quartz sand. In addition, FA sorption was faster under dynamic than static conditions. Furthermore, the fitted $\mathrm{C}_{\mathrm{eq}}^{*}$ values for the experiments conducted in the presence of quartz sand were much lower than those in the absence of quartz sand. Further, the fitted $\mathrm{C}_{\mathrm{eq}}^{*}$ values for the experiments conducted in the absence of quartz sand were higher under dynamic than static conditions. This was an anticipated result because of the enhanced undisturbed mixing during dynamic conditions in the absence of quartz sand. In the presence of quartz sand, the fitted $\mathrm{C}_{\mathrm{eq}}^{*}$ values were higher under static than dynamic conditions. This finding was attributed to possible interactions between $\mathrm{TiO}_{2}$ nanoparticles and quartz sand. Furthermore, the lower fitted $\mathrm{C}_{\mathrm{eq}}^{*}$ values observed in the presence of quartz sand was an expected observation, because the mass of sorbents was increased considerably with the addition of quartz sand. Note that $C_{\mathrm{eq}}^{*}$ is given in units of $(\mathrm{mg} / \mathrm{g})$. However, the percentage of FA removal was consistently higher in the presence than the absence of quartz sand (see Figure 2). 
Table 1. Fitted sorption parameter values.

\begin{tabular}{|c|c|c|c|c|c|c|c|c|c|}
\hline \multicolumn{6}{|c|}{$\begin{array}{c}\text { Experimental } \\
\text { Conditions }\end{array}$} & \multicolumn{2}{|c|}{$\begin{array}{c}k_{\mathrm{p} 2} \\
(\mathrm{~g} / \mathrm{mg} \cdot \mathrm{d})\end{array}$} & \multicolumn{2}{|c|}{$\begin{array}{c}\mathrm{C}_{\mathrm{eq}}^{*} \\
(\mathrm{mg} / \mathrm{g})\end{array}$} \\
\hline No & $\begin{array}{c}\mathrm{C}_{\mathrm{FA}} \\
(\mathrm{mg} / \mathrm{L})\end{array}$ & $\begin{array}{c}\mathrm{C}_{\mathrm{TiO} 2} \\
(\mathrm{mg} / \mathrm{L})\end{array}$ & $\begin{array}{c}\text { Quartz Sand } \\
\text { (g/vial) }\end{array}$ & $\mathrm{pH}$ & $\begin{array}{c}\text { Is } \\
(\mathrm{mM})\end{array}$ & Static & Dynamic & Static & Dynamic \\
\hline 1 & 3 & 100 & - & - & - & 0.073 & 0.076 & 8.37 & 9.18 \\
\hline 2 & 5 & 100 & - & - & - & 0.012 & 0.030 & 12.16 & 16.15 \\
\hline 3 & 8 & 100 & - & - & - & 0.031 & 0.056 & 22.76 & 26.79 \\
\hline 4 & 5 & 100 & - & 4 & - & 0.154 & 0.155 & 13.63 & 13.77 \\
\hline 5 & 5 & 100 & - & 7.5 & - & 0.075 & 0.091 & 17.54 & 16.35 \\
\hline 6 & 5 & 100 & - & 10 & - & 0.029 & 0.059 & 12.27 & 11.66 \\
\hline 7 & 5 & 100 & - & - & 1 & 0.032 & 0.070 & 15.37 & 15.64 \\
\hline 8 & 5 & 100 & - & - & 50 & 0.041 & 0.063 & 12.00 & 15.63 \\
\hline 9 & 5 & 100 & - & - & 100 & 13.74 & 54.66 & 13.22 & 16.26 \\
\hline 10 & 3 & 100 & 14 & - & - & 313.4 & 8000.9 & 0.0037 & 0.0030 \\
\hline 11 & 5 & 100 & 14 & - & - & 89.2 & $10,000.0$ & 0.0048 & 0.0041 \\
\hline 12 & 8 & 100 & 14 & - & - & 417.7 & 3275.2 & 0.0092 & 0.0068 \\
\hline 13 & 5 & 100 & 14 & 4 & - & 168.0 & 3444.3 & 0.0063 & 0.0053 \\
\hline 14 & 5 & 100 & 14 & 7.5 & - & 779.2 & 4011.9 & 0.0057 & 0.0057 \\
\hline 15 & 5 & 100 & 14 & 10 & - & 630.1 & $10,000.0$ & 0.0061 & 0.0050 \\
\hline 16 & 5 & 100 & 14 & - & 1 & 443.0 & 3932.5 & 0.0065 & 0.0053 \\
\hline 17 & 5 & 100 & 14 & - & 50 & 545.2 & 701.7 & 0.0064 & 0.0051 \\
\hline 18 & 5 & 100 & 14 & - & 100 & 898.1 & 1327.9 & 0.0051 & 0.0051 \\
\hline
\end{tabular}

\section{Conclusions}

The sorption of FA onto $\mathrm{TiO}_{2}$ nanoparticles in the absence and presence of quartz sand under static and dynamic conditions, at $25^{\circ} \mathrm{C}$ was investigated. The experimental results from this work suggested that FA sorption was faster and more pronounced in the presence of quartz sand. Typical $\mathrm{pH}$ and ionic strength variations did not significantly affect the FA sorption process. The experimental data were satisfactorily fitted by the pseudo-second order model, indicating that the sorption mechanism was chemisorption. The experiments were conducted with clean quartz sand. Of course, the interaction of FA with quartz sand could be somewhat different if the quartz sand was not cleaned or if natural soil had been used. Assuming that FA could be relatively mobile in natural soil and sediments and could potentially contaminate the aquatic environment with numerous adverse effects on living organisms and to human health, its removal is essential. The present study suggested that combination of the sorbents $\mathrm{TiO}_{2}$ and quartz sand can effectively remove FA from aqueous solutions.

Author Contributions: A.S.S. worked on the experimental design, collected, and analyzed the data, and wrote the first draft of the paper. C.V.C. supervised the research and contributed to the writingreviewing and editing of the manuscript. All authors have read and agreed to the published version of the manuscript.

Funding: This research has received funding from the Partnership for Research and Innovation in the Mediterranean Area (PRIMA), under grant agreement number: 1923-InTheMED.

Institutional Review Board Statement: Not applicable.

Informed Consent Statement: Not applicable. 
Data Availability Statement: Data is contained within the article.

Acknowledgments: The authors are thankful to Sosa Fountouli and Rika Sarika for valuable laboratory assistance and Bill Katzourakis for expert help with the nonlinear least squares regression software ColloidFit.

Conflicts of Interest: The authors declare that there are no conflict of interest.

\section{References}

1. Liyanage, C.P.; Yamada, K. Impact of population growth on the water quality of natural water bodies. Sustainability 2017, 9, 1405. [CrossRef]

2. Schwarzenbach, R.P.; Escher, B.I.; Fenner, K.; Hofstetter, T.B.; Johnson, C.A.; Von Gunten, U.; Wehrli, B. The challenge of micropollutants in aquatic systems. Science 2006, 313, 1072-1077. [CrossRef] [PubMed]

3. Oliveira, S.V.; Moraes, E.M.; Adorno, M.A.; Varesche, M.B.; Foresti, E.; Zaiat, M. Formaldehyde degradation in an anaerobic packed-bed bioreactor. Water Res. 2004, 38, 1685-1694. [CrossRef] [PubMed]

4. Cogliano, V.J.; Grosse, Y.; Baan, R.A.; Straif, K.; Secretan, M.B.; El Ghissassi, F. Summary of IARC monographs on formaldehyde, 2-butoxyethanol, and 1-tert-butoxy-2-propanol. Environ. Health Perspect. 2005, 113, 1205-1208. [CrossRef]

5. Moussavi, G.; Yazdanbakhsh, A.; Heidarizad, M. The removal of formaldehyde from concentrated synthetic wastewater using $\mathrm{O}_{3} / \mathrm{MgO} / \mathrm{H}_{2} \mathrm{O}_{2}$ process integrated with the biological treatment. J. Hazard. Mater. 2009, 171, 907-913. [CrossRef]

6. Priya, K.R.; Sandhya, S.; Swaminathan, K. Kinetic analysis of treatment of formaldehyde containing wastewater in UAFB reactor. Chem. Eng. J. 2009, 148, 212-216. [CrossRef]

7. Paliulis, D. Removal of formaldehyde from synthetic wastewater using natural and modified zeolites. Pol. J. Environ. Stud. 2016, 25, 251-257. [CrossRef]

8. Glaze, W.H.; Koga, M.; Cancilla, D. Ozonation byproducts. 2. Improvement of an aqueous-phase derivatization method for the detection of formaldehyde and other carbonyl compounds formed by the ozonation of drinking water. Environ. Sci. Technol. 1989, 23, 838-847. [CrossRef]

9. Mursics, J.; Urbancl, D.; Goricanec, D. Process of formaldehyde and volatile organic compounds' removal from waste gases. Appl. Sci. 2020, 10, 4702. [CrossRef]

10. Becher, G.; Ovrum, N.M.; Christman, R.F. Novel chlorination by-products of aquatic humic substances. Sci. Total Environ. 1992, 117, 509-520. [CrossRef]

11. Weinberg, H.S.; Glaze, W.H.; Krasner, S.W.; Sclimenti, M.J. Formation and removal of aldehydes in plants that use ozonation. Am. Water Work. Assoc. 1993, 85, 72-85. [CrossRef]

12. Mitch, W.A.; Schreiber, I.M. Degradation of tertiary alkylamines during chlorination/chloramination: Implications for formation of aldehydes, nitriles, halonitroalkanes, and nitrosamines. Environ. Sci. Technol. 2008, 42, 4811-4817. [CrossRef] [PubMed]

13. Kobayashi, N.; Sugimoto, N.; Kubota, R.; Nomoto, M.; Ikarashi, Y. Identification of the cause of formaldehyde water pollution and the future issues on the management of unregulated chemicals in drinking water. J. Jpn. Risk Anal. 2013, 23, 65-70.

14. IPCS International Programme on Chemical Safety. Formaldehyde. In Environmental Health Criteria 89; World Health Organization: Geneva, Switzerland, 1989; p. 219.

15. IARC International Agency for Research on Cancer. Wood dust and formaldehyde. In IARC Monographs on the Evaluation of Carcinogenic Risks to Humans; IARC: Lyon, France, 1995; Volume 62, pp. 217-375.

16. Krasner, S.W.; McGuire, M.J.; Jacangelo, J.G.; Patania, N.L.; Regan, K.M.; Aieta, E.M. The occurrence of disinfection by-products in US drinking water. J. Am. Water Work. Assoc. 1989, 81, 41-53. [CrossRef]

17. Tomkins, B.A.; Mcmahon, J.M.; Caldwell, W.M.; Wilson, D.L. Liquid chromatographic determination of total formaldehyde in drinking water. J. Assoc. Off. Anal. Chem. 1989, 72, 835-839. [CrossRef] [PubMed]

18. Huck, P.M.; Anderson, W.B.; Rowley, S.M.; Daignault, S.A. Formation and removal of selected aldehydes in a biological drinking-water treatment process. J. Water Supply Res. Technol. Aqua 1990, 39, 321-333.

19. Zoutberg, G.R.; de Been, P. The Biobed EGSB (expanded granular sludge bed) system covers shortcomings of the upflow anaerobic sludge blanket reactor in the chemical industry. Water Sci. Technol. 1997, 35, 183-188. [CrossRef]

20. Kumar, A. Biodegradation kinetics of phenol and catechol using Pseudomonas putida MTCC 1194. Biochem. Eng. J. 2005, 22, 151-163. [CrossRef]

21. Cvetkovic, Z.; Suhadolnik, Z.; Grilc, V. Biological treatment of wastewater from a phenol-formaldehyde resins production. Chem. Eng. J. 1998, 2, 262-273.

22. Wang, M.; Wen, B.; Fan, B.; Zhang, H. Study on adsorption mechanism of silicate adsorbents with different morphologies and pore structures towards formaldehyde in water. Colloids Surf. A Physicochem. Eng. Asp. 2020, 599, 124887. [CrossRef]

23. Fam, Y.; Imae, T. Catalytic oxidation of formaldehyde in water by calcium phosphate-based Pt composites. R. Soc. Chem. Adv. 2015, 5, 15944-15953. [CrossRef]

24. Parmar, S.S.; Grosjean, D. Sorbent removal of air pollutants from museum display cases. Environ. Int. 1991, 17, 39-50. [CrossRef]

25. Sekine, Y.; Nishimura, A. Removal of formaldehyde from indoor air by passive type air-cleaning materials. Atmos. Environ. 2001, 35, 2001-2007. [CrossRef] 
26. Georgopoulou, M.P.; Chrysikopoulos, C.V. Evaluation of carbon nanotubes and quartz sand for the removal of formaldehyde(2,4-dinitrophenylhydrazine) from aqueous solutions. Ind. Eng. Chem. Res. 2018, 57, 17003-17012. [CrossRef]

27. Fountouli, T.V.; Chrysikopoulos, C.V.; Tsanis, I.K. Effect of salinity on formaldehyde interaction with quartz sand and kaolinite colloid particles: Batch and column experiments. Environ. Earth Sci. 2019, 78, 152. [CrossRef]

28. Mueller, N.; Nowack, B. Exposure modeling of engineered nanoparticles in the environment. Environ. Sci. Technol. 2008, 42, 4447-4453. [CrossRef] [PubMed]

29. Jeevanandam, J.; Barhoum, A.; Chan, Y.S.; Dufresne, A.; Danquah, M.K. Review on nanoparticles and nanostructured materials: History, sources, toxicity and regulations. Beilstein J. Nanotechnol. 2018, 9, 1050-1074. [CrossRef]

30. Batley, G.; Kirby, J.; McLaughlin, M. Fate and risks of nanomaterials in aquatic and terrestrial environments. Acc. Chem. Res. 2013, 46, 854-862. [CrossRef]

31. Sygouni, V.; Chrysikopoulos, C.V. Characterization of $\mathrm{TiO}_{2}$ nanoparticle suspensions in aqueous solutions and $\mathrm{TiO}_{2}$ nanoparticle retention in water-saturated columns packed with glass beads. Chem. Eng. J. 2015, 262, 823-830. [CrossRef]

32. Syngouna, V.I.; Chrysikopoulos, C.V. Inactivation of MS2 bacteriophage by titanium dioxide nanoparticles in the presence of quartz sand with and without ambient light. J. Colloid Interface Sci. 2017, 497, 117-125. [CrossRef]

33. Syngouna, V.I.; Chrysikopoulos, C.V. Bacteriophage MS2 and titanium dioxide heteroaggregation: Effects of ambient light and the presence of quartz sand. Colloids Surf. B Biointerfaces 2019, 180, 281-288. [CrossRef] [PubMed]

34. Molla, M.A.I.; Furukawa, M.; Tateishi, I.; Katsumata, H.; Kaneco, S. Optimization of alachlor photocatalytic degradation with nano- $\mathrm{TiO}_{2}$ in water under solar illumination: Reaction pathway and mineralization. Clean Technol. 2018, 1, 141-153. [CrossRef]

35. Hadjiivanov, K.J.; Kissurski, D.G. Surface chemistry of titania (anatase) and titania supported catalysts. Chem. Soc. Rev. 1996, 25, 61-69. [CrossRef]

36. Haider, A.J.; Jameel, Z.N.; Al-Hussaini, I.H.M. Review on: Titanium dioxide applications. Energy Procedia 2019, 157, 17-29. [CrossRef]

37. Kiser, M.A.; Westerhoff, P.; Benn, T.; Wang, Y.; Perez-Rivera, J.; Hristovski, K. Titanium nanomaterial removal and release from wastewater treatment plants. Environ. Sci. Technol. 2009, 43, 6757-6763. [CrossRef]

38. Carp, O.; Huisman, C.L.; Reller, A. Photoinduced reactivity of titanium dioxide. Prog. Solid State Chem. 2004, 32, 33-177. [CrossRef]

39. Zainab, N.J. Synthesis of $\mathrm{TiO}_{2}$ Nanoparticles by Sol-Gel Method using Laser Ablation for Nano Paint Application. Ph.D. Thesis, University of Baghdad, Physics Department, Baghdad, Iraq, 2015.

40. Robichaud, C.O.; Uyar, A.E.; Darby, M.R.; Zucker, L.G.; Wiesner, M.R. Estimates of upper bounds and trends in nano-TiO 2 production as a basis for exposure assessment. Environ. Sci. Technol. 2009, 43, 4227-4233. [CrossRef]

41. Abbas, M. Experimental investigation of titanium dioxide as an adsorbent for removal of Congo red from aqueous solution, equilibrium and kinetics modeling. J. Water Reuse Desalination 2020, 10, 251-266. [CrossRef]

42. Yin, X.; Meng, X.; Zhang, Y.; Zhang, W.; Sun, H.; Lessl, J.T.; Wang, N. Removal of V (V) and Pb (II) by nanosized TiO 2 and ZnO from aqueous solution. Ecotoxicol. Environ. Saf. 2018, 164, 510-519. [CrossRef]

43. Awwad, A.; Amer, M. Al-aqarbeh, M. $\mathrm{TiO}_{2}$-kaolinite nanocomposite prepared from the Jordanian Kaolin clay: Adsorption and thermodynamics of $\mathrm{Pb}$ (II) and Cd (II) ions in aqueous solution. Chem. Int. 2020, 6, 168-178.

44. Saleem, H.; Zaidi, S.J. Developments in the application of nanomaterials for water treatment and their impact on the environment. Nanomaterials 2020, 10, 1764. [CrossRef] [PubMed]

45. Yuan, Q.; Wu, Z.; Jin, Y.; Xiong, F.; Huang, W. Surface chemistry of formaldehyde on rutile $\mathrm{TiO}_{2}(110)$ surface: Photocatalysis vs thermal-catalysis. J. Phys. Chem. C 2014, 118, 20420-20428. [CrossRef]

46. Zhu, K.; Xia, Y.; Tang, M.; Wang, Z.-T.; Jan, B.; Lyubinetsky, I.; Ge, Q.; Dohnálek, Z.; Park, K.T.; Zhang, Z. Tracking site-specific C-C coupling of formaldehyde molecules on rutile $\mathrm{TiO}_{2}(110)$. J. Phys. Chem. C 2015, 119, 14267-14272. [CrossRef]

47. Feng, H.; Liu, L.; Dong, S.; Cui, X.; Zhao, J.; Wang, B. Dynamic processes of formaldehyde at terminal Ti sites on the rutile $\mathrm{TiO}_{2}(110)$ surface. J. Phys. Chem. C 2016, 120, 24287-24293. [CrossRef]

48. Setvin, M.; Hulva, J.; Wang, H.; Simschitz, T.; Schmid, M.; Parkinson, G.S.; Di Valentin, C.; Selloni, A.; Diebold, U. Formaldehyde adsorption on the anatase $\mathrm{TiO}_{2}$ (101) surface: Experimental and theoretical investigation. J. Phys. Chem. C 2017, 121, 8914-8922. [CrossRef]

49. US EPA. Revision 1, Determination of Carbonyl Compounds by High Performance Liquid Chromatography (HPLC); Method 8315A; US EPA: Washington, DC, USA, 1996.

50. Nash, T. The colorimetric estimation of formaldehyde by means of the Hantzsch reaction. Biochem. J. 1953, 55, 416-421. [CrossRef]

51. Loveland, J.P.; Ryan, J.N.; Amy, G.L.; Harvey, R.W. The reversibility of virus attachment to mineral surfaces. Colloids Surf. A Phys. Eng. Asp. 1996, 107, 205-221. [CrossRef]

52. Chrysikopoulos, C.V.; Aravantinou, A.F. Virus inactivation in the presence of quartz sand under static and dynamic batch conditions at different temperatures. J. Hazard. Mater. 2012, 233-234, 148-157. [CrossRef] [PubMed]

53. Chrysikopoulos, C.V.; Syngouna, V.I.; Vasiliadou, I.A.; Katzourakis, V.E. Transport of Pseudomonas putida in a three-dimensional bench scale experimental aquifer. Transp. Porous Media 2012, 94, 617-642. [CrossRef]

54. Chrysikopoulos, C.V.; Aravantinou, A.F. Virus attachment onto quartz sand: Role of grain size and temperature. J. Environ. Chem. Eng. 2014, 2, 796-801. [CrossRef]

55. Ho, Y.-S.; McKay, G. Pseudo-second order model for sorption processes. Process Biochem. 1999, 34, 451-465. [CrossRef] 
56. Qiu, H.; Lv, L.; Pan, B.; Zhang, Q.; Zhang, W.; Zhang, Q. Critical review in adsorption kinetic models. J. Zhejiang Univ. Sci. A 2009, 10, 716-724. [CrossRef]

57. Sotirelis, N.P.; Chrysikopoulos, C.V. Heteroaggregation of graphene oxide nanoparticles and kaolinite colloids. Sci. Total Environ. 2017, 579, 736-744. [CrossRef]

58. Syngouna, V.I.; Giannadakis, G.I.; Chrysikopoulos, C.V. Interaction of graphene oxide nanoparticles with quartz sand and montmorillonite colloids. Environ. Technol. 2020, 41, 1127-1138. [CrossRef] [PubMed]

59. Katzourakis, V.E.; Chrysikopoulos, C.V. Fitting the transport and attachment of dense biocolloids in one dimensional porous media: ColloidFit. Groundwater 2017, 55, 156. [CrossRef]

60. Kieu, L.; Boyd, L.; Idriss, H. Modelling of the adsorption of formic acid and formaldehyde over rutile $\mathrm{TiO}_{2}(110)$ and $\mathrm{TiO}_{2}(011)$ clusters. J. Mol. Catal. A Chem. 2001, 176, 117-125. [CrossRef]

61. Zhao, D.; Sheng, G.; Hu, J.; Chen, C.; Wang, X. The adsorption of Pb (II) on $\mathrm{Mg}_{2} \mathrm{Al}$ layered double hydroxide. Chem. Eng. J. 2011, 171, 167-174. [CrossRef]

62. Yang, H.; Sun, X.; Liu, S.X.; Liu, J.L.; Ren, X.M. Low-cost and environmental-friendly kaolinite-intercalated hybrid material showing fast formaldehyde adsorbing behavior. Chem. Sel. 2016, 1, 2181-2187. [CrossRef]

63. Lloyd, M.; Maurice, O.S.; Aoyi, O.; Leswifi, T. $\Upsilon$. Sorption characteristics of mixed molecules of glutaraldehyde from water on mesoporous acid-amine modified low-cost activated carbon: Mechanism, isotherm, and kinetics. J. Chem. 2015, 2015, 757256. [CrossRef]

64. Salman, M.; Athar, M.; Shafique, U.; Rehman, R.; Ameer, S.; Ali, M.Z.; Azeem, M. Removal of formaldehyde from aqueous solution by adsorption on kaolin and bentonite: A comparative study. Turk. J. Eng. Environ. Sci. 2012, 36, $263-270$.

65. Kulikauskaite, D.; Paliulis, D. Formaldehyde removal from wastewater applying natural zeolite. Environ. Prot. Eng. 2015, 7, 443-448.

66. Esposito, A.; Pagnanelli, F.; Lodi, A.; Solisio, C.; Veglio, F. Biosorption of heavy metals by Sphaerotilus natans: An equilibrium study at different $\mathrm{pH}$ and biomass concentrations. Hydrometallurgy 2001, 60, 129-141. [CrossRef]

67. Das, N.; Das, D. Recovery of rare earth metals through biosorption: An overview. Rare Earths 2013, 31, 933-943. [CrossRef]

68. Xie, J.; Lin, Y.; Li, C.; Wu, D.; Kong, H. Removal and recovery of phosphate from water by activated aluminum oxide and lanthanum oxide. Powder Technol. 2015, 269, 351-357. [CrossRef]

69. Fountouli, T.V.; Chrysikopoulos, C.V. Effect of clay colloid particles on formaldehyde transport in unsaturated porous media. Water 2020, 12, 3541. [CrossRef]

70. Mandzy, N.; Grulke, E.; Druffel, T. Breakage of $\mathrm{TiO}_{2}$ agglomerates in electrostatically stabilized aqueous dispersion. Powder Technol. 2005, 160, 121-126. [CrossRef]

71. Boncagni, N.T.; Otaegui, J.M.; Warner, E.; Curran, T.; Ren, J.; DeCortalezzi, M.M. Exchange of $\mathrm{TiO}_{2}$ nanoparticles between streams and streambeds. Environ. Sci. Technol. 2009, 43, 7699-7705. [CrossRef]

72. Laak, T.L.; Gebbink, W.A.; Tolls, J. The effect of $\mathrm{pH}$ and ionic strength on the sorption of sulfachloropyridazine, tylosin, and oxytetracycline to soil. Environ. Toxicololy Chem. 2006, 24, 904-911. [CrossRef]

73. Jiang, J.K.; Oberdorster, G.; Biswas, P. Characterization of size, surface charge, and agglomeration state of nanoparticle dispersions for toxicological studies. J. Nanoparticle Res. 2009, 11, 77-89. [CrossRef] 